\title{
Quaternary laminar calcretes with bee nests: evidences of small-scale climatic fluctuations, Eastern Canary Islands, Spain
}

\author{
A.M. Alonso-Zarza ${ }^{a}, *$ P.G. Silva ${ }^{b}$ \\ a Departamento de Petrología y Geoquímica, Facultad de Ciencias Geológicas, Universidad Complutense de Madrid, \\ 28040 Madrid, Spain \\ b Departamento de Geología, Universidad de Salamanca, Escuela Politécnica Superior de Ávila, 05003 Ávila, Spain
}

\begin{abstract}
Thick laminar calcrete profiles are common on the surface of the eastern Canary Islands of Lanzarote and Fuerteventura. This paper reports the study of one profile from Lanzarote (Macher profile) and one from Fuerteventura (Tefía profile). These profiles are about $2 \mathrm{~m}$ thick. The Macher profile is developed on basaltic host rocks and consists of two main horizons: a lower horizon in which white veins of laminated micrite penetrate cracks, and an upper laminar horizon. The Tefía profile is cumulative and consists, from base to top, of massive, laminar, and massive and laminar-brecciated horizons. Highlighted in the study of these profiles are the presence of ooids, the complex structure of the laminar horizons, and the occurrence of fossil bee nests (Celliforma). Ooids consist of a nucleus of clay, micrite and etched grains coated with envelopes of micrite and clay (mainly palygorskite). Organic films favoured both the precipitation of carbonate and the adhesion of clays when the ooids formed in the soil. The laminar horizons consist of a centimetre-scale alternation of massive micrite with varied amounts of ooids and detrital grains with laminated micrite. This alternation indicates the small-scale periods of sedimentation, erosion and soil formation in the upper part of a relatively stable surface. These small-scale alternations may reflect climatic vegetation changes in which arid periods are represented by micrite with ooids, while laminated micrite reflects a better-developed vegetation of the wet periods. Celliforma occur as ovoid larval cells with more or less rounded bases and a flat top. The cells are about $3 \mathrm{~cm}$ long and $1.5 \mathrm{~cm}$ in diameter. Their wall is about $5 \mathrm{~mm}$ thick, and is commonly laminated. Celliforma is interpreted as fossil nests of solitary bees. Their presence in the laminar horizon is evidence for the existence of a vegetation cover containing angiosperms.
\end{abstract}

Keywords: laminar calcretes; trace fossils; palaeoclimate fluctuations; Quaternary; Canary Islands; Celliforma

\section{Introduction}

* Corresponding author. Tel.: +34-91-3944915; Fax: +34-91-5442535.

E-mail address: alonsoza@geo.ucm.es (A.M. Alonso-Zarza).
Quaternary calcretes in the two easternmost Canary Islands, Lanzarote and Fuerteventura, constitute the main evidence for the development of mature soil profiles on the volcanic host rocks 
of these islands. Moreover, the calcretes show a number of biogenic features due to the activity of plants and insects, providing data on the initial stages of the development of recent Canary ecosystems. The calcretes formed on volcanic rocks of different types and of mainly Pleistocene age (post Brunhes-Matuyama reversal: $<0.78 \mathrm{Myr}$ ), but in Fuerteventura they also formed on late Pleistocene alluvial fan deposits. In this island, the development of calcretes is so spectacular that it looks like an island coated by calcretes. Despite this, most of the geological work carried out in the Canaries has focused on volcanic rocks.

In this paper two calcrete profiles are described, one in Lanzarote and the other in Fuerteventura. They are very mature and commonly show a thick cap laminar horizon. However, the most outstanding feature is the abundance of distinctive trace fossils with ovoid shapes (cells) about $3 \mathrm{~cm}$ long and $1.5 \mathrm{~cm}$ in diameter. These are the nests of solitary bees or wasps, and are generally included in the ichnogenus Celliforma (Brown, 1935; Retallack, 1984). Celliforma has been recognised in different types of fossil soils from the Eocene (Ducreux et al., 1988) to the present. Their occurrence is important because it reveals not only the presence of this type of insect within the soils, but also provides significant data on the vegetation of the surrounding environment (Thackray, 1994; Genise et al., 2000).

The aim of this work was to show that these calcretes and the trace fossils they contain provide important data for understanding Pleistocene climates, the prevailing ecosystems and their role in soil-forming processes.

\section{Geological setting}

Fuerteventura and Lanzarote are the two easternmost islands of the Canary archipelago (Fig. 1), which is located close to the Atlantic seaboard of western Africa. Present-day climatic conditions reflect the scarcity of water, and predominant arid conditions characterise both islands. Their climate is influenced by the cold Canary Current, which reduces precipitation and causes high temperatures equivalent to those recorded in the

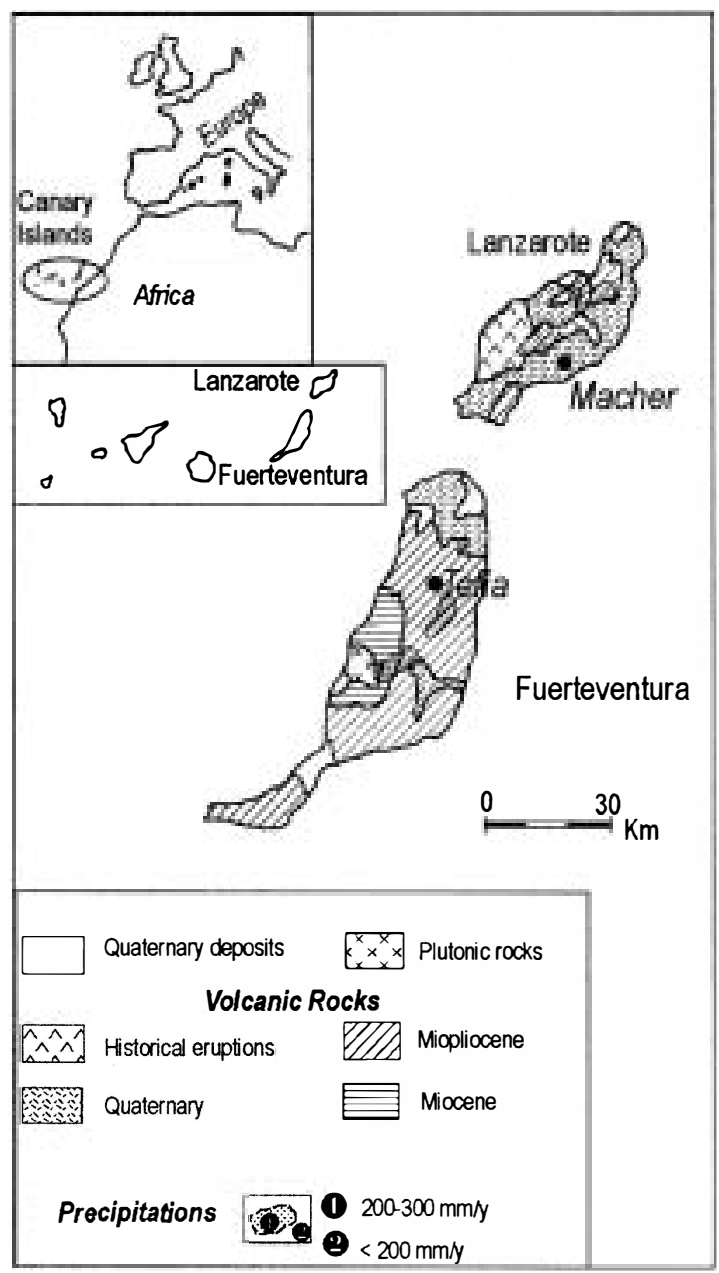

Fig. 1. Location and geological map of the main rock types that outcrop in Lanzarote and Fuerteventura. Situation of the studied profiles and recent range of precipitation in the islands are also shown.

Western Sahara Desert (Danmati, 1997). Both islands have rainfall averages of $105 \mathrm{~mm}$, ranging from 53 to $220 \mathrm{~mm}$, although the latter is only recorded at the central and highest areas of both islands during wintertime.

The two islands are formed by a variety of mostly volcanic rocks. There is, however, an ancient massif of plutonic rocks in Fuerteventura (Fig. 1) called the Basal Complex. In both islands, the volcanic rocks are divided into four different subaerial volcanic series (I to IV) of mainly basaltic nature (Fúster et al., 1968a,b). As classically 
established, Series II and III are Pleistocene (s.l.) in age. Palaeomagnetic surveys carried out in Lanzarote indicate that Series II-III have a consistent normal polarity, attributed to the Brunhes epoch $(<0.78 \mathrm{Myr}$, Carracedo and RodríguezBadiola, 1993). Series IV is Holocene in age and includes some of the historical eruptions of Lanzarote (1730-1824 A.D.).

In Lanzarote, the Quaternary sediments include uplifted beach deposits, which in some cases are interbedded with volcanic materials. This allows the establishment of relative timing. The calcrete studied in this paper (Macher profile) is located in the SE part of the island, overlying the basalts of Series III (Pleistocene s.l.). Former interpretations (Fúster et al., 1968b) considered these materials younger than the Atlantic Ouljian episode (isotopic stage 5; ca. 140-85 Kyr), based on their relationship with a $10-\mathrm{m}$ uplifted beach. Recent investigations based on $\mathrm{Th} / \mathrm{U}$ series dating indicate that the marine deposits belonging to the isotopic substages $5 \mathrm{e}$ and $5 \mathrm{c}$ never reach $6 \mathrm{~m}$ above sea level (Zazo et al., 1997), as earlier stated by Radke (1985) for Fuerteventura. In addition, radiometric K/Ar dating of the volcanic materials close to the studied calcrete profile gave ages of 1.2 to $0.24 \mathrm{Myr}$ (Coello et al., 1992), suggesting a probable Middle Pleistocene age for calcrete development.

In Fuerteventura, Pliocene and Quaternary deposits include not only uplifted beaches and eolian sands, but also alluvial fan deposits, glacis and calcretes (Criado, 1988; Martínez de Pisón and Quirantes, 1994), which are more prominent than in Lanzarote. Calcretes developed either on alluvial fan deposits or on volcanic rocks during two main periods of semi-arid conditions; the first took place during the Pliocene and the more recent during the late Pleistocene s.1. (Criado, 1988). During the latter, a characteristic landform of the island, the so-called 'tableros' formed. These 'tableros' are fan surfaces hardened by extensive calcrete development (Criado, 1988). The studied profile (Tefía profile) is located in the eastern part of the island. The calcrete is developed at the top of a recent alluvial fan surface fed by the Barranco de la Cruz. This calcrete or 'tablero' is entrenched $2-3 \mathrm{~m}$ by the recent arroyo (ram- bla). This geomorphological position suggests this calcrete may have started to form during the Late Pleistocene.

Palaeoclimatic trends for the eastern Canary Islands have been established on the basis of previous pedological and marine terrace studies (Meco and Stearns, 1981; Meco and Pomel, 1985; Petit-Maire et al., 1986; Danmati, 1997; Zazo et al., 1997). Extensive calcrete development in Fuerteventura may have started prior to an arid period that occurred about 30000 years B.P. (Petit-Maire et al., 1986). However, parts of the studied calcretes contain accumulations of fossil Anthophora nests, which are thought to be preferably produced under more humid conditions than those found in Late Pleistocene and Holocene soils (Petit-Maire et al., 1986; Danmati, 1997). Because precise age relationships between volcanic materials and calcretes are still uncertain, it is difficult to unravel their specific position within the Late Pleistocene climatic sequence. In any event, the aforementioned concentration of $\mathrm{An}$ thophera nests in some of the horizons of the studied profiles suggests that calcretes developed under climates with changing humidity regimes.

\section{Techniques}

Two calcrete profiles were selected and sampled for study. Stained thin sections of calcretes and Celliforma cells were studied using transmitted light microscopy. Scanning electron microscope (SEM) observations were performed with a JEOL 6400 working at $20 \mathrm{kV}$. Fracture surfaces were gold-covered, whereas polished thin sections were carbon-covered for backscattered electron imagery. The mineralogy of the samples was determined using a Philips XRD system operating at $40 \mathrm{kV}$ and $30 \mathrm{~mA}$ with monochromated CuK. radiation. Clay mineralogy was determined after treating the powdered samples with $5 \% \mathrm{HCl}$ for $24 \mathrm{~h}$.

\section{Calcrete profiles}

The calcrete profiles (Fig. 2) were selected for 


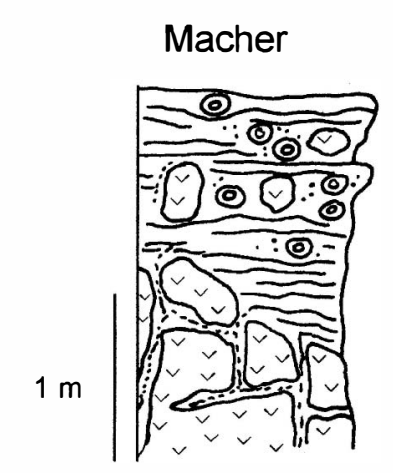

\section{Tefía}
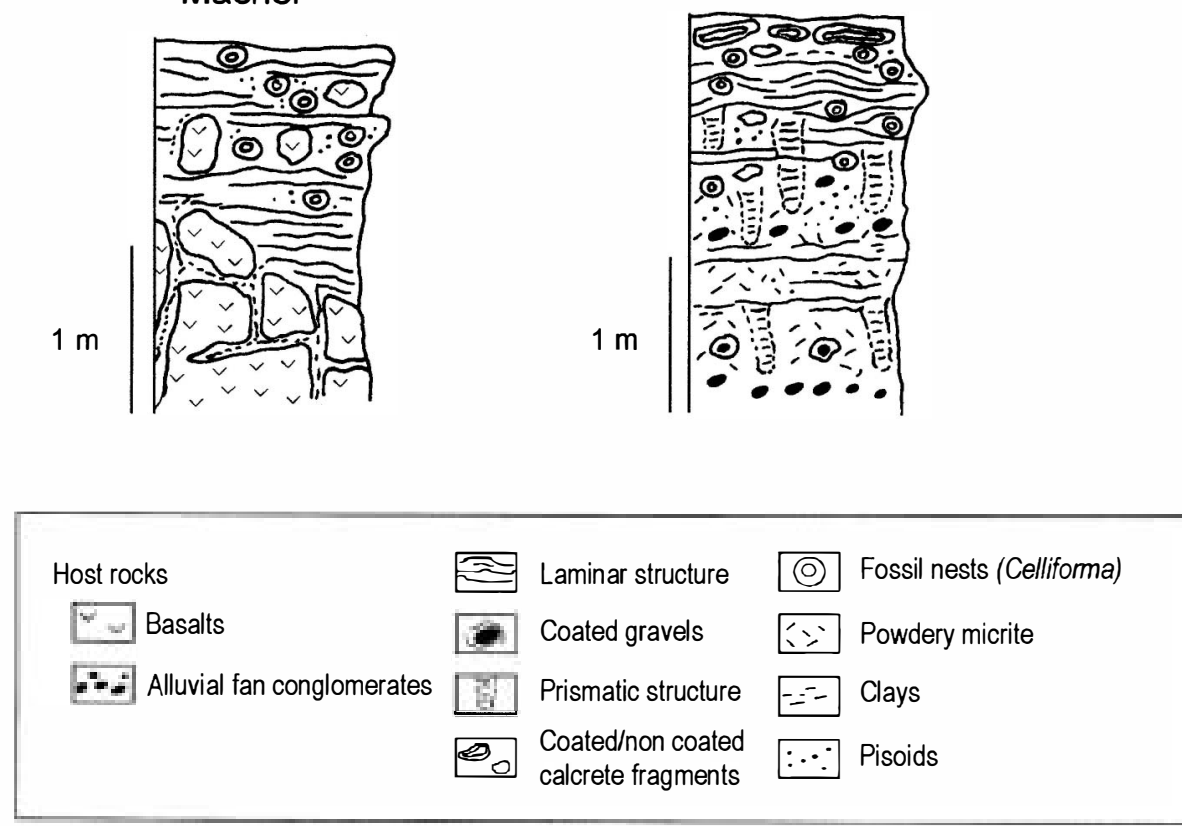

Fig. 2. Sketch of the Macher and Tefía profiles. Note that the laminar horizons form the main part of both profiles. Celliforma occurrences are also shown.

their good outcropping and because they contained fossil nests (Celliforma). These two profiles show the significance of these pedogenic carbonates for understanding the recent evolution of the palaeoclimates and palaeovegetation of the Canary Islands.

\subsection{Macher profile}

This profile (Figs. 2 and 3A) is directly developed on the black basalts of Series II-III (Fúster et al., 1968a), which are Middle to Late Pleistocene in age (Coello et al., 1992; Carracedo and Rodríguez-Badiola, 1993). The profile is on a lowgradient $(<10 \%)$ volcanic slope situated $195 \mathrm{~m}$ above sea level in an interfluve position between two main arroyos dissecting the SW slope of the Montaña Blanca. Here, basalt weathering and calcrete development took place in the absence of significant erosion or sedimentation processes, indicating landscape stabilisation during the Late Quaternary.

The Macher profile is up to $2 \mathrm{~m}$ thick and consists of a lower horizon of weathered and fragmented basalts in which white veins of laminated micrite penetrate (Fig. 3A). The veins are up to several millimetres wide and may be more than $1 \mathrm{~m}$ in length, follow the morphology of previous cracks, and may have contributed to their opening and to the weathering of the basalts. Internally, they are formed of micrite, in which ooids of up to $1 \mathrm{~mm}$ in diameter occur, either dispersed between the micrite groundmass or following irregular laminae. Fragments of basalts are very common within the micrite groundmass and sometimes constitute the nuclei of the ooids.

The upper horizon of the profile is the real horizon of carbonate accumulation, and is about $1.2 \mathrm{~m}$ thick. The horizon is laminated, with laminae about $10 \mathrm{~cm}$ thick and very irregular (Fig. 3A), very hard and separated from each other by films of marls, clays or powdery micrite. Internally, the laminae are zoned with a relatively homogeneous inner area of micrite with ooids and etched volcanic fragments. This inner massive 

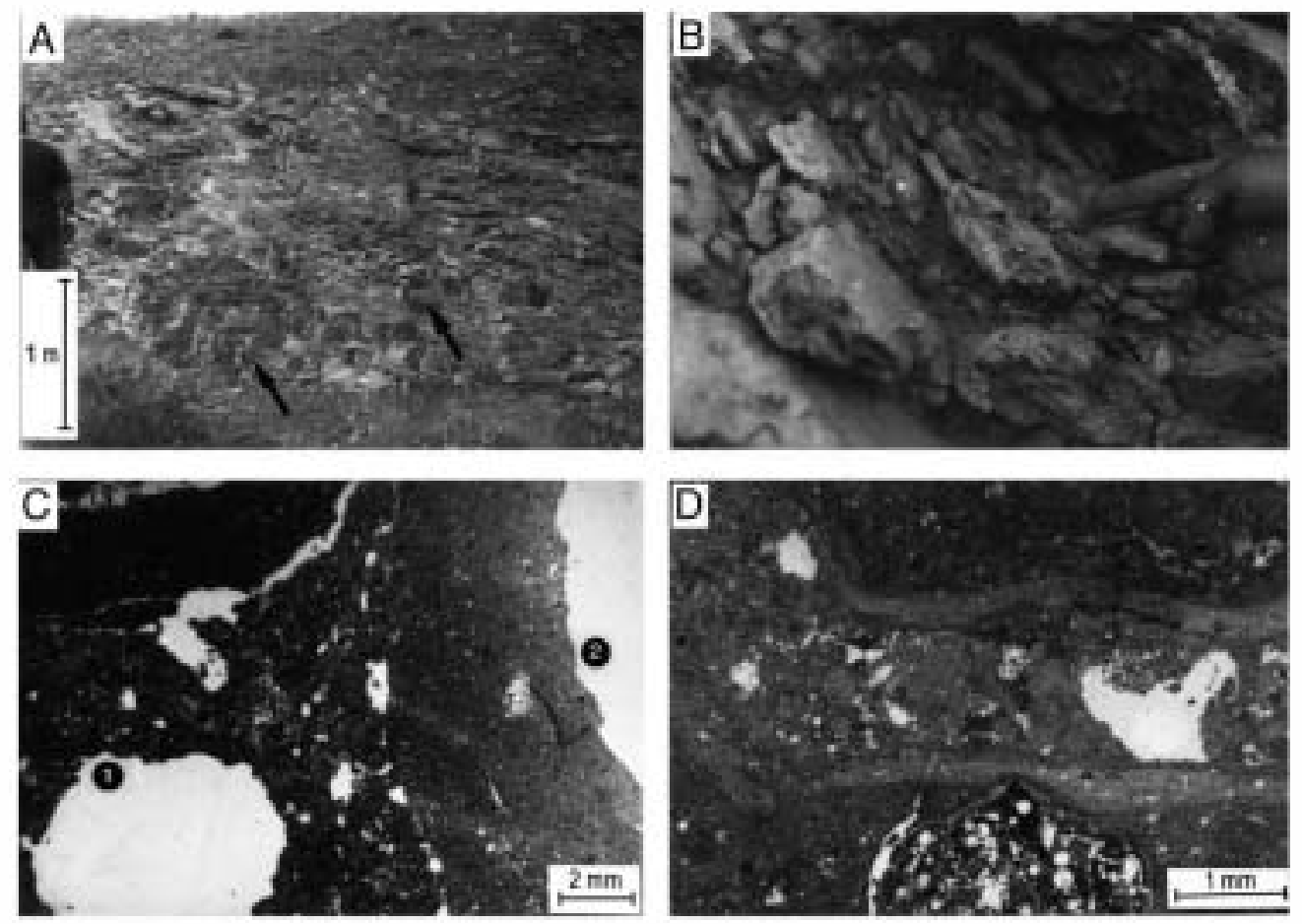

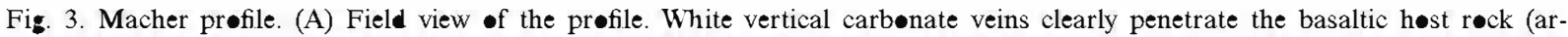

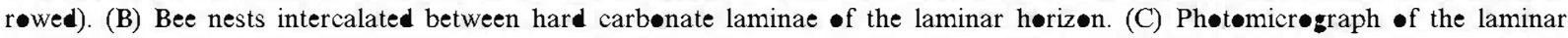

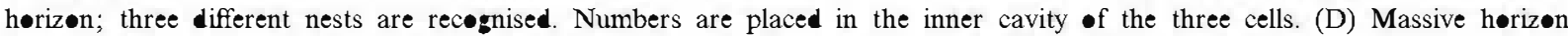
shøwing the presence of vølcanic fragments (løwer part) and a linear structure filled by $\bullet$ ids and micrite.

part is coated externally by layered micrite. Within the micrite groundmass (the inner area) the ooids show no orientation or grading. They vary in size from 0.1 to $2 \mathrm{~mm}$ and commonly show a nucleus that may be either a volcanic fragment or micrite. The nuclei are coated by regular laminae of micrite in which there is alternation between lighter orange coatings containing more clay and darker envelopes richer in micrite. The concentric laminae commonly include small volcanic fragments. The layered micrite (outer area) is about $1 \mathrm{~cm}$ thick and coats any discontinuity within the calcrete. Lamination is due to the alternation of homogeneous micrite with layers containing ooids similar to those previously described.

Within this profile the fossil nests of Celliforma are clearly visible in its softer parts (Fig. 3B), but they are also present within the hardest upper part of the calcrete (Fig. 3C). Some linear structures (Fig. 3D) are also recognised in the upper horizon of the profile. These structures show an external laminated zone and are filled with ooids similar to those described in the calcrete.

\subsection{Tefia profile}

This profile is developed on the topmost surface of gravel-dominated alluvial fan systems coming from the east. The fan surface is extensively affected by calcrete development, having an overall very gentle $2^{\circ}$ slope. This makes it a large tabler $\bullet-$ type surface, such as those developed during the Late Pleistocene (Criado, 1988). The studied profile, located at the upper apex zone of the alluvial fan surface, is at an elevation similar to the Macher profile, at $180 \mathrm{~m}$ above sea level.

The gravels that constitute the host rock are mostly formed by clasts of basalts that are very corroded and floating within the carbonate. Relics of the gravels are very prominent at the base of the profile as well as at about $1 \mathrm{~m}$ from the base (Fig. 2). This suggests that the deposition of grav- 

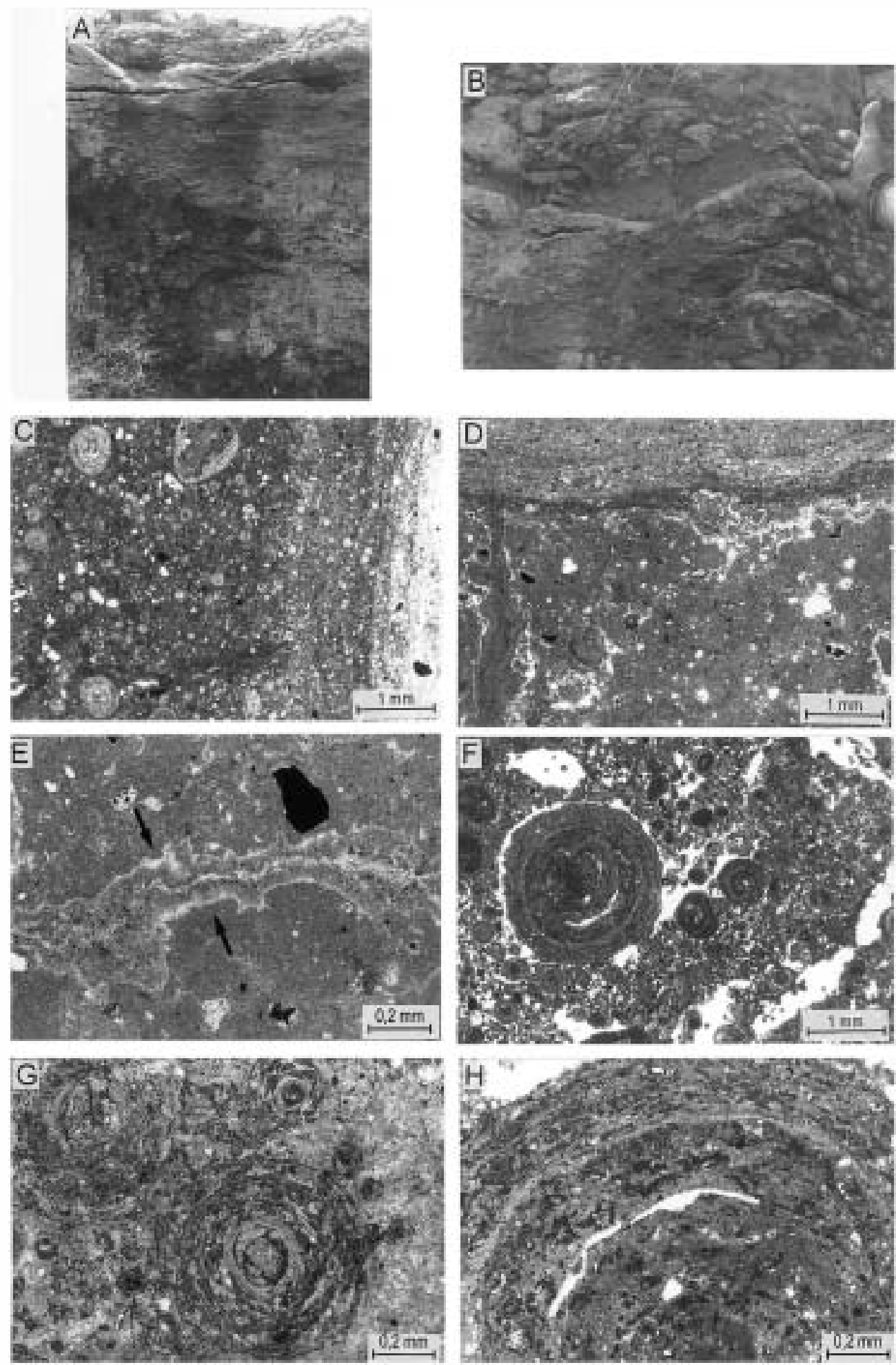
els disrupted the formation of the first calcrete profile. Later calcrete development overlapped that previously formed. The disruption of calcrete profile development by sedimentary events has been noted in semi-arid SE Spain, where the thickening of calcrete profiles was controlled by sedimentary processes occurring during the final phases of fan development (Alonso-Zarza et al., 1998). The profile described here (Fig. 4A,B) can be considered a cumulative palaeosol in the Kraus (1999) sense. The lower part of the calcrete, which is $1 \mathrm{~m}$ thick, is formed by two horizons: a lower horizon $(0.7 \mathrm{~m}$ thick) of powdery micrite with floating coated gravels and vertical prismatic structure, and an upper laminar horizon of $0.3 \mathrm{~m}$. The upper part, which is $1.5 \mathrm{~m}$ thick, also consists of two horizons similar to those previously described, but both are thicker than in the lower part, and the laminar horizon is very hardened and brecciated at the top. Celliforma occur mainly in these upper horizons (Fig. 4B).

Internally, the lower powdery horizons consist of a micrite groundmass in which ooids are distributed homogeneously or in cracks within the micrite. The cracks are generally regular, suggesting they were initially desiccation cracks. In these lower horizons the ooids are up to $0.6 \mathrm{~mm}$ in diameter and consist of nuclei of dark and dense micrite coated by light concentric and regular laminae of clay (palygorskite) and micrite. Some ooids are undergoing recrystallisation, as shown by the substitution of the lighter envelopes by dark micrite.

The upper laminar horizons are formed by centimetre-thick massive layers of micrite with ooids as well as detrital siliciclastic grains that alternate with millimetre-scale layered micrite (Fig. 4C). The contact between the micrite with ooids and the layered micrite is sharp and irregular (Fig. 4D). Occasionally, irregular cracks are present. These cracks, either desiccation or root cracks, show complex infill by micrite coating their walls and ooids in their inner zone. However, the most noticeable feature is the presence of a first coating of oriented palygorskite cutans (Fig. 4E). The occurrence of palygorskite lining different types of soil structures such as solutional channels, ped surfaces and skeletal grains is common in other calcretes, such as the Quaternary calcretes from the Kalahari (Watts, 1980). In the massive laminae, the ooids are up to $1.8 \mathrm{~mm}$ in diameter. In general, these layers show a high ooid content making up more than $80 \%$ of the layers (Fig. 4F). The nuclei are either siliciclastic grain or an aggregate of clay and micrite. The coatings of the ooids are formed by thin (micron-scale) laminae of occasionally oriented clays, as shown by the high birefringence and the extinction pattern, that alternate with micrite laminae (Fig. 4G). Both clay (mostly palygorskite) and micrite envelopes commonly include lime-size siliciclastic grains (Fig. $4 \mathrm{H}$ ). The ooids are embedded in a mass of micrite crystals.

Ooids from the two profiles are very similar, as shown by backscattered and SEM images. Therefore, their general microstructure can be described independent of profile source. Backscattered images show some variations in the composition of the different laminae of the ooids, some containing more grains are more massive while others are neatly laminated (Fig. 5A,B). Differences in colour indicate differences in composition, being the lighter laminae richer in calcite. SEM images show the high content of organic features within the coatings (Fig. 5C). Needle-fibre calcite crystals coat organic films on clay and micrite aggregates

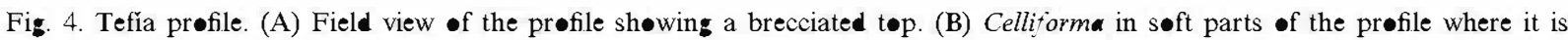

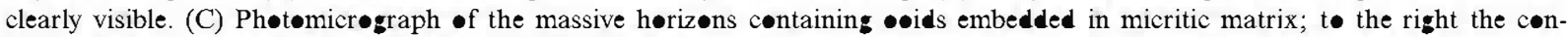

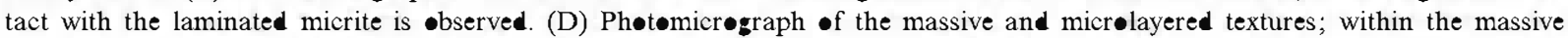

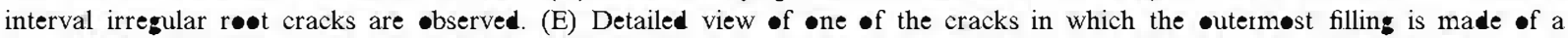

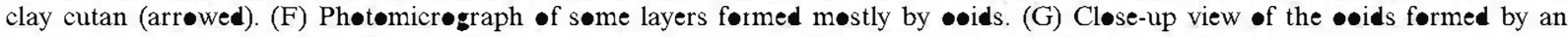
alternation of darker and lighter laminae. The lighter laminae are enriched in clays, whereas the darker laminae are made møstly

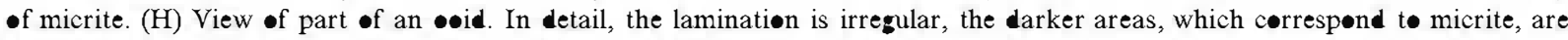

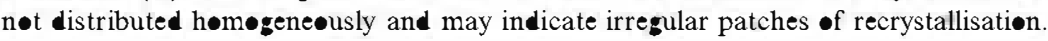



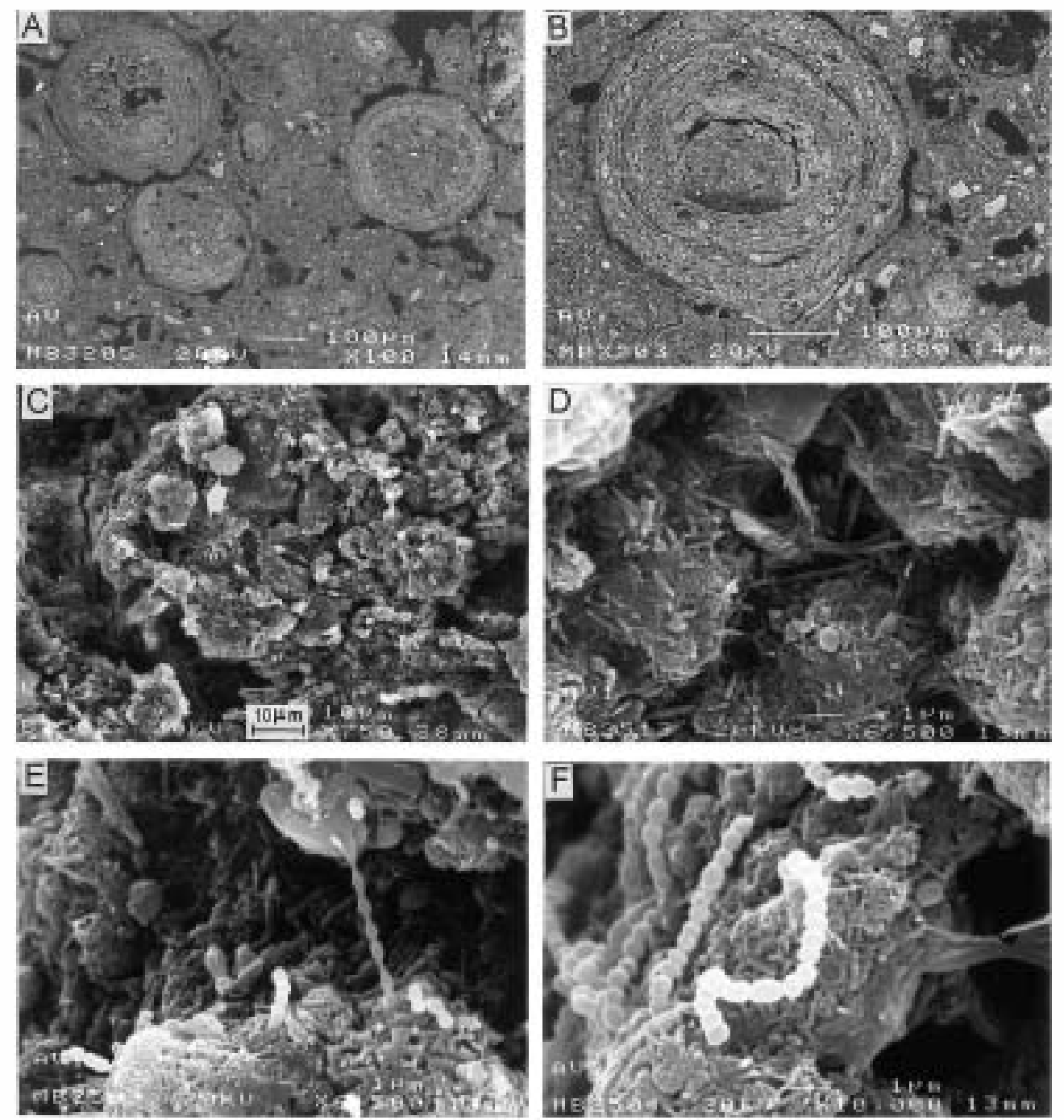

Fig. 5. SEM image. (A) Backscattered image of the ooid embedded in micrite matrix with detrital grains. The composition of the nuclei of the ooid and the matrix is similar. (B) Backscattered image of an ooid; the lighter laminae are enriched in Ca with respect to the rest of the ooid or the micrite matrix, indicating areas of preferential precipitation of calcite. (C) SEM image of the nuclei and the coating of an ooid, the nucleus is formed by an aggregation of particles (clay, detrital grains, micrite). (D) Closeup view of the aggregation of particles coated by needle-fibre calcite. (E) Detailed view of the arrowed part of $\mathrm{C}$ showing the presence of a variety of organic structures and needle-fibre calcite. (F) Mucus film coated by chains of bacteria and needle-fibre crystals.

(Fig. 5D). Bacterial-like bodies are associated with these organic films (Fig. 5E,F).

The contact between these ooidal fabrics and the millimetre-scale layered micrite is sharp and in some cases is outlined by the presence of loose microspar. The layered micrite consists of micrite layers that alternate with small $(0.2 \mathrm{~mm}$ in diam- eter) ooids. Alveolar septal structures are present, but were less common than expected.

In the topmost part of the profile, the laminated micrite is brecciated and fragmented (Fig. 2). Moreover, the laminated micrite is cut by horizontal and vertical cracks that also penetrate the massive ooidal part. 

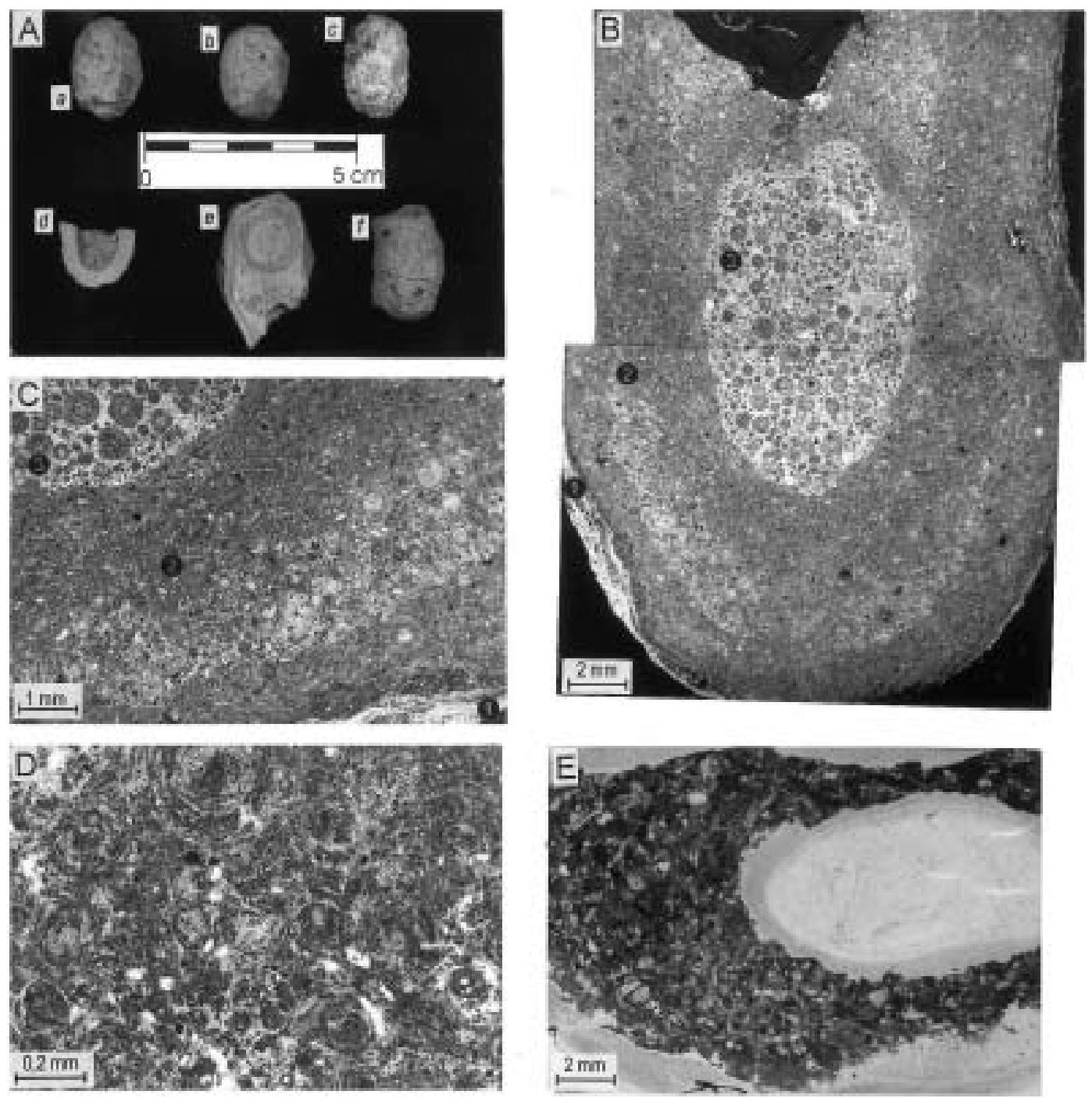

Fig. 7. Celliforma. (A) View of the hand samples of the bee cells: (a, b), external morphology (Macher profile); (c) external morphology (Quaternary dunes of Corralejos); (d, e) cross-sectional view showing internal morphology of the cells either isolated or included within the calcrete (Tefía profile); (f) external morphology of a bee cell (Tefía profile). (B) Photomicrograph with polarised light of a thin section of Celliforma; (1) external laminated part; (2) wall; (3) inner cavity filled later on by ooids. (C) Detailed view of B, showing the same three parts; the wall is relatively complex as is formed by irregular laminae some richer in ooids and others richer in clays. (D) Detailed view of the ooids forming the wall, clearly more irregular and smaller than ooids from the calcretes. (E) Photomicrograph of a thin section of Celliforma from Corralejos dunes; the wall is not formed by ooids or clays but by carbonate and quartz sand-sized grains embedded in micrite.

distinctive horizons indicate that these profiles are somehow different from the classic calcrete profiles described by Esteban and Klappa (1983) or Machette (1985). Three main features are noteworthy in the profiles analysed: (1) the abundance of ooids, (2) the fact that laminar horizons form most of the profiles, and (3) the presence of Celliforma, which is described and discussed below. 


\subsection{The ooids}

Coated grains are very common in calcrete profiles (Calvet and Juliá, 1983; Hay and Wiggins, 1980), palustrine carbonates (Freytet and Plaziat, 1982; Alonso-Zarza et al., 1992) and peritidal settings (Mazzullo and Birdwell, 1989). The problem of the study of these coated grains starts with their classification (Peryt, 1983; Richter, 1983). In the present study, owing to their size (less than $2 \mathrm{~mm}$ in diameter) and the regularity of their coatings, they have been named ooids, regardless of their origin.

In the studied calcretes, ooids occur in four different situations: (a) in laminae of massive and powdery micrite, in these laminae the percentage of ooids may vary between 10 and $80 \%$ and the laminae commonly contain siliciclastic grains also embedded within micrite; (b) in filling cracks of micrite fabrics; (c) forming layers within the laminated micrite beds and (d) within Celliforma nests. In all cases the internal structure of the ooids is the same.

This internal structure of the ooids (see description above), their associated occurrence with higher amounts of detrital grains, and the fact that some coatings contain detrital grains, suggest that these ooids were very probably moved or rolled within the soils. Clays could have adhered to the ooids' surface and were probably oriented tangentially, resulting in the birefringence of their laminae. Adhesion of clays could also be favoured by the presence of organic films (Fig. 5C). Micrite could precipitate biogenically on the mucus films that also coated the ooids. Thus, the presence of the ooids reveals periods of movement of loose particles within the soil. This process has been documented also in calcretes from Tanzania (Hay and Reeder, 1978). The movement of the ooids may have been induced mechanically or by roots, root hairs or other soil organisms, such as hymenopterans that dig into the soil. Calvet and Julia (1983) describe the presence of ooids in relation to recent root systems in NE Spain. These authors show how the degree of preservation of the organic structures in these coated grains changes from the nuclei to the outer part of the ooids. This process is also recognised in the two profiles analysed but in a different way. For example, some light coatings containing organic films are being replaced by micrite, which is interpreted as a process of recrystallisation of precipitates formed on the organic films, such as needlefibre crystals (Fig. 5D). Micrite can also replace clay coatings as described by Hay and Reeder (1978).

\subsection{The laminar horizons}

The presence of laminar horizons at the top of calcrete profiles is an indicator of a high maturity stage. When the top is brecciated the maturity stage reached is Stage VI (Machette, 1985; Wright, 1991). The formation of these horizons has been widely discussed in recent years (Verrecchia et al., 1995; Wright et al., 1996; AlonsoZarza et al., 1998) and calcretes showing them have been interpreted as rootcretes (Jones, 1992) or rhizogenic calcretes (Wright et al., 1995) since it is commonly accepted that the main agent responsible for the formation of these horizons is a horizontal root system (Alonso-Zarza, 1999). However, cyanobacteria (Verrecchia et al., 1995), bacteria, fungi (Verrecchia and Verrecchia, 1994) and lichens (Klappa, 1979) may also be important. Detailed and controversial discussions of the origin of these horizons were held by Wright et al. $(1995,1997)$ and Freytet et al. (1997). Those discussions and replies were focused mostly on a specific section of the Languedoc region containing Microcodium, which is absent in the study profiles.

The morphology and petrographic data clearly point to a biogenic, root-mat origin for the laminar horizons of Macher and Tefía. Where water is scarce, plant roots have two possibilities. The first is to penetrate the substrate to reach either groundwater or water within discontinuities of the host rocks. This strategy is most likely recorded in the Macher profile where vertical laminae of carbonates fill the cracks of the basalt rock (Fig. 6). The second is to extend horizontally to retain the maximum amount of water, which results in the formation of horizontal laminae of carbonates (Fig. 6) (Alonso-Zarza, 1999). This mechanism may be important in very permeable substrates 
or on very hard host rocks or soil profiles, the case of the studied profiles.

The fact that the laminar horizon is not only formed by laminated micrite but also by an alternation of laminated micrite with centimetre-scale laminae of ooids and some siliciclastic grains embedded within massive micrite, indicates alternation between periods of ooid formation and periods of formation of fine-scale laminations. This may reflect the alternation between periods of clastic sedimentation and erosion, and periods of more intense root activity. Thus, the centimetrescale laminae of ooids and siliciclastic grains embedded within the micrite represent successive stages of sedimentation, reworking and soil formation, which can be reconstructed from the soil microstructure. In the first stage, soil formation processes lead to the formation of the ooids and to the biogenic and non-biogenic precipitation of micrite within the soil, and so to the cementation of these laminae. In a second stage, plant roots extended horizontally give rise to the formation of the laminated micrite (Fig. 6).

In brief, these alternations (Fig. 6) represent small-scale calcrete profiles that evolved as a response to short periods of sedimentation followed by periods of soil formation. Therefore, the overall calcrete profiles can be considered as resulting from the addition of many small-scale profiles, which in turn record multiple stages of soil formation, erosion and reworking (Verrecchia, 1987; Fedoroff et al., 1994). The alternation of these two microfabrics, over more than $1 \mathrm{~m}$, points to climatic control. It is hypothesised that sedimentation could occur in more arid periods with very sparse vegetation, while soil formation processes indicate slightly more humid periods that favoured the growth of relatively denser vegetation. Evidence includes the presence of Celliforma within some laminar horizons, and the presence of clay cutans at the base of the laminated micrite cutting the more massive micrite with ooids. However, more data on the relationship between calcretes and alluvial fan deposits are needed to confirm this hypothesis.

Brecciation of the uppermost part of the profiles reflects degradation of the calcrete profiles due to the lack of renewed sedimentation. This provides a space (host rock) for the development of another small-scale soil profile. Therefore, present-day vegetation and the erosion of the calcrete top are favouring its brecciation. A similar situation has been described by Alonso-Zarza et al. (1998) in Pleistocene calcretes from SE Spain.

The formation of these calcretes is essentially through vertical aggradation successive laminae of ooids, sediment and massive micrite to the top of the profiles (Fig. 6). This millimetre-scale lamination may be interrupted by deposition of a thicker bed of sediments (Tefía profile. Fig. 6), that reflects major changes in the evolution of the calcrete profile and may indicate larger scale climatic changes.

\section{Petrography of the fossil nests}

The fossil nests occur in softer parts of the calcrete profiles (Figs. 3B and 4B), and also lithified within the calcretes (Figs. 3C and 7A). They are about $3 \mathrm{~cm}$ long and $1.5 \mathrm{~cm}$ in diameter (Fig. 7A) and consist of a conspicuous wall about $5 \mathrm{~mm}$ thick, which is commonly laminated. Cells are ovoid in shape with a more or less rounded base and a relatively flat top.

The external part of the cell wall is irregular (Fig. 7A) and is formed by an alternation of micritic, organic and clay-rich laminae; their thickness is about $0.7 \mathrm{~mm}$ (Fig. 7B). The inner part of the wall consists of a mixture of ooids, micrite, clay and organic relics (Fig. 7C). The mixture is not total as diffuse lamination is observed due to variations in clay, micrite or organic content, but also to the size of the ooids (Fig. 7C). In general, ooids forming the wall are smaller $(\mathbf{0 . 1}-\mathbf{0 . 5} \mathrm{mm})$ than those of the surrounding calcretes, and their coatings are less regular (Fig. 7D). The inner cavity of the cell is either empty or filled with ooids (Fig. 7C). These ooids are very similar to the ooids present in the calcretes.

We have also recognised the ichnogenus Celliforma in dunes from Corralejo in northern Fuerteventura. The morphology and size of the cells are similar to those described herein, but these nests are made of carbonate sand-size grains (fragments of foraminifera, echinoids, 
and other fossils) embedded in a micritic matrix (Fig. 7E).

The morphology of these cells allows these trace fossils to be assigned to the ichnogenus $\mathrm{Cel}$ liforma, first described by Brown (1935) who proposed this name "to include all fossil fillings of chambers purporting to have been made originally by unknown mining Hymenoptera". Later, Retallack (1984) amended the identification of Celliforma and defined this ichnogenus as: "vasifform, globular or subcylindrical chambers or internal moulds of chambers; distal or inner end rounded; proximal or outer end either truncated irregularly or capped by a flat or conical closure, bearing spiral or concentric grooves on its inner surface; walls polished and smooth so that internal mould is easily separated from rock matrix". The cells described in this paper clearly fit this description. However, we did not find spiral caps, such as those described by Retallack (1984), or Domínguez and Coca (1998) amongst others, were found.

The cells studied here bear similarities to beetle pupal chambers (Johnston et al., 1996), but the evidence indicates they are clearly Celliforma: (1) Ellis and Ellis-Adam (1993) found spiral caps in sandy dunes of Fuerteventura (at Corralejo) and Lanzarote. (2) Beetle chambers show different morphologies, they are more rounded and much larger than the structures studied here. Some chambers show a prominent exit hole on the long axis of the cell (Johnston et al., 1996), which is not seen in Celliforma. Other structures attributed to beetles have a meniscate internal filling absent in the cells of this study or in any cells commonly described for the Canary Islands (Petit-Maire et al., 1986; Danmati, 1997). (3) In the overall literature referring to the Canary Islands, these structures are commonly considered as Anthophora (or Hymenopteran nests), and not as beetle chambers (Fúster et al., 1968b; Edwards and Meco, 2000).

Based on different morphological aspects of Celliforma, a number of ichnospecies have been defined (e.g. Brown, 1934; Retallack, 1984; Ducreux et al., 1988; Domínguez and Coca, 1998). At the moment, the most simple and precise classification of Celliforma into various ichnospecies is that proposed by Genise and Bown (1994), which is based on the morphology of the cells. In the present case, however, it is preferable to classify the structures at the ichnogeneric level, as a more detailed ichnologic analysis is needed for precise taxonomic classification. Moreover, Celliforma ichnospecies exhibit such diverse morphology that a detailed taxonomic review of the ichnogenus is needed (Genise and Bown, 1994; Genise and Hazeldine, 1998). For example, some ichnospecies previously considered to be Celliforma are now included in the ichnogenus Palmiraichnus (Genise and Hazeldine, 1998).

Another problem when analysing these trace fossils is identifying which type of insect is responsible for the trace. There is common agreement that Celliforma are produced by hymenopterans. Both wasps and bees construct similar cells and nests (Trackray, 1994; Mader, 1999). The lining and smooth surfaces can be attributed to bees or wasps since both not only excavate soil materials and pack the walls of the cell, but moisten it with saliva (Brown, 1934; Trackray, 1994). However, bees may polish the cell walls and smear Dufour's gland secretion on them (Batra, 1980). This favours the cementation of the cell wall and may explain its laminated microstructure (Fig. 7B,C), which seems to be a common feature of some bee nests such as those built by Ptilothrix relata (Emphorini). These bees form mud pellets by mixing water or saliva with soil particles. They attach successive mud pellets to form the laminated cell wall (Genise and Hazeldine, 1998).

The presence of Anthophora nests in the Canaries has been very commonly noted in the geological literature (Fúster et al., 1968b). In a study on the recent sediments and soils of Fuerteventura, Petit-Maire et al. (1986) and Danmati (1997) recognised individual or multiple Anthophora nests, which they attributed to a large hymenoptera with black and yellow bands, that lives in the islands. Ellis and Ellis-Adam (1993) attribute these nests to an anthophorid of the genus Eucera or to a closely related genus Tetralonia, both very common at present in both Lanzarote and Fuerteventura. It seems that solitary burrowing bees constructed these nests. The fact that in calcretes the nests are made of ooids and clays, 
and in the dunes they are formed of carbonate grains indicates that the bees collected the material to construct their nests from nearby areas. These insects mixed materials with secretions to build nests that are relatively solid structures, more resistant to erosion than the surrounding sediments (Genise and Bown, 1994). The presence in soils of Celliforma, or other ichnofacies included in the Coprinisphaera, is controlled by ecological parameters (e.g. vegetation, climate and soil) rather than by depositional processes (Genise et al., 2000). In general, Coprinisphaera ichnofacies characterise palaeosol development under herbaceous communities. More specifically, the dominance of hymenopteran traces, such as Celliforma, is indicative of arid soils, with moderate plant growth, good drainage, exposure to the sun (Ratcliffe and Fagerstron, 1980; Genise and Bown, 1994; Genise et al., 2000), and the presence of angiosperms, which provide pollen to the bees.

\section{Discussion and conclusions}

The two calcrete profiles studied in this paper illustrate the importance of vegetation and soil fauna in the formation of fossil soils. This hypothesis, which in most contexts seems to be obvious, is of special importance in the eastern Canary Islands where climatic conditions are extreme and the establishment of a vegetation cover leading to soil formation processes is very difficult. Although the relationships between calcretes and alluvial fan development in both islands are at the moment poorly understood, field observations indicate that, in Fuerteventura, calcretes developed on the whole fan surface, which may also be indicative of climatically controlled alluvial fan systems (Wright and Alonso-Zarza, 1990).

The extensive occurrence of calcretes in the two islands, and the convergence of their microfabrics, even though they have developed in different geomorphic contexts, indicate that climate and vegetation (climatically induced) controlled the formation and characteristics of these calcretes. The integration of information suggests that the calcretes formed in a relatively stable landscape characterised by periods of low sedimentation rates. In this landscape, sparse vegetation cover including angiosperms developed. This vegetation survived under conditions of low water availability, as indicated by the hymenopteran traces as well as the presence of palygorskite (Sancho et al., 1992), whose formation was favoured by the increase of the $\mathrm{Mg} / \mathrm{Ca}$ ratio within the soil as the result of calcite precipitation within the soil. However, some water had to be available for the maintenance of these ecosystems as well as for the weathering of the host rocks. Calcretes have been considered indicators of arid to semi-arid climates (Goudie, 1983; Wright, 1991), and calcretes from the Canary Islands clearly reflect these conditions. Some studies performed on the Quaternary evolution of the Islands considered that calcretes and dunes were indicators of relatively more arid periods, while the occurrence of Anthophora nests provided evidence of more humid times (Petit-Maire et al., 1986) since they were included in clayish palaeosols. In a mineralogical and sedimentological study of Late Pleistocene eolian deposits and palaeosols of Lanzarote and Fuerteventura, Danmati (1997) concluded that the alternation of eolian deposits and palaeosols reflected climatic oscillations, in which palaeosols represented the wetter periods favouring weathering of the basalts and neoformation of smectites and pedogenesis, whereas the eolian deposits represented more arid periods. In a recent study, Edwards and Meco (2000) reported cells of solitary bees associated with littoral deposits of the last Interglacial Stage (IS 5) and concluded that the climatic conditions were arid, but less-so than at present. In the studied cases, bee nests were associated with the calcretes. This, together with the necessary interplay of vegetation to form the calcretes, suggests they most likely formed during relatively more humid periods (always in the general context of an arid to semi-arid climate), while the more arid periods were favourable to extensive alluvial fan development. Sancho and Meléndez (1992), who studied Pleistocene calcretes from the Ebro Basin in Spain, concluded that calcretes formed in a general arid to semi-arid climate. Periodical oscillations favoured the formation of calcretes in wetter periods while clastic deposition occurred in more arid times. 
Detailed analyses of the profiles indicate that they are the result of multiple phases of soil formation, erosion and deposition, as proposed by Fedoroff et al. (1994), Sanz and Wright (1994) and Alonso-Zarza et al. (1998). In the present case, the alternation of these processes reflects minor scale climatic oscillations, the wetter periods represented by the microlaminated fabrics and the more arid by massive and ooidal microfabrics.

In essence, the analysis of the Macher and Tefía profiles allows the inference that, apart from the well known large-scale climatic changes of the Late Pleistocene, small-scale climatic fluctuations occurred in the eastern Canary Islands during the same period. Unfortunately, the lack of good chronological data for these palaeosols and the interbedded clastic deposits does not allow the assignment of calcrete development to one specific Late Pleistocene climatic period. In this work, however, we have tried to show that the study of these calcretes is of special importance in understanding not only the climatic variability, but also in the supply of data that help reconstruct the dominant ecosystems and their evolution in these two arid islands.

\section{Acknowledgements}

We would like to thank Dr. V.E. Peñalver and Dr. V. Monserrat for their help in understanding bee behaviour and insect trace fossils. Dr. C. Arias is thanked for assistance with binocular photography. Dr. G. Mángano, Dr. G.J. Retallack and Dr. E. Verrecchia are thanked for their review of the manuscript.

\section{Ref erences}

Alønsø-Zarza, A.M., Calv•, J.P., García del Cura, M.A., 1992. Palustrine sedimentation and asseciated features, grainification and pseudo-microkarst, in the Middle Miøcene (Intermediate Unit) of the Madrid Basin, Spain. Sediment. Ge•l. 76, 4361.

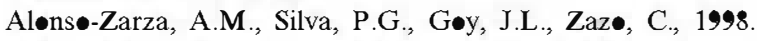
Fan-surface dynamics and biøgenic calcrete develøpment: interactiøns during ultimate phases of fan evelution in the

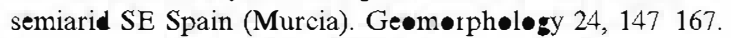

Aløns-Zarza, A.M., 1999. Initial stages of laminar calcrete formation by røots: examples from the Neøgene of central Spain. Sediment. Ge•l. 126, 177191.

Batra, S.W.T., 1980. Ecøløg, behavi॰r, pherømen, parasites and management of the sympatric vernal bees Colletes inaequalis, $C$. thoracicus and $C$. validus. J. Kans. Entømøl. Sec. 53, 509538.

Brøwn, R.W., 1934. Celliforma spirifer, the fossil larval chambers of mining bees. J. Wash. Acad. Sci. 24, 532539.

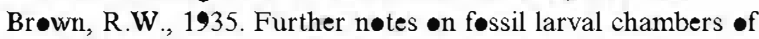
minin bees. J. Wash. Acad. Sci. 225, 526528

Calvet, F., Juliá, R., 1983. Pisøids in the caliche prøfiles of Tarragena (NE Spain). In: Peryt, T.M. (Ed.), Cıated Grains. Springer, Berlin, pp. 737 .

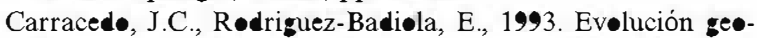
lógica y magmática de la Isla de Lanzar te (Islas Canarias). Rev. Acal. Canar. Cienc. 4, 2568.

Cøell•, J., Cantagrel, J.M., Hernán, F., Fúster, J.M., Ibarrıla, E., Ancøechea, E., Casquet, C., Jamønd, C., Díaz de Téran, J.R., Cendrer $\bullet$ A., 1992. Evølution of the Eastern volcanic ridge of the Canary Islands based on new $\mathrm{K}$ Ar data.

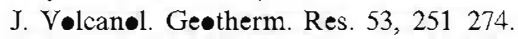

Criade, C., 1988. Evølución Geømørfølógica de Fuerteventura. Ph.D. thesis, Universidad de La Laguna, Tenerife.

Danmati, B., 1997. Mineralegical and sedimentelegical characterization of quaternary eølian formatiøns and paleøs ls in Fuerteventura and Lanzarıte (Canary Island, Spain). In: Mec•, J., Petit-Maire, N. (Eds.), Climates of the Past. Serviciø de Publicaciønes, Universidad de Las Palmas de Gran Canaria, pp. 7177.

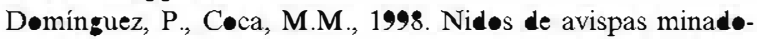

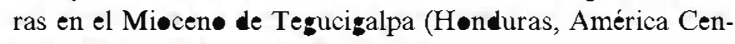

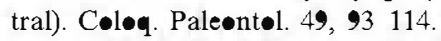

Ducreux, J.L., Billaud, Y., Truc, G., 1988. Traces fossiles d'insectes dans les palésøls rouges de l'Eøcéne supérieur du n॰rd-est du Massif central français: Celliforma arvernensis

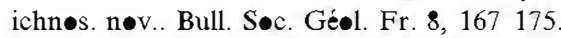

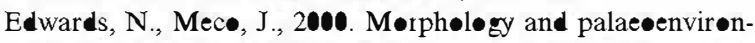
mental significance of brøds cells of Quaternary grøunnestin s litary bees (Hymenøptera, Apidae) frøm Fuerteventura, Canary Islands, Spain. Prøceedings of the Geøløgists's Assøciation, Løndon, pp. 173183.

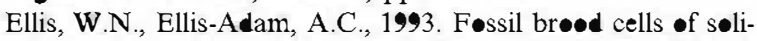
tary bees on Fuerteventura and Lanzarıte, Canary Islands (Hymenøptera: Apøidea). Ent. Ber. Amst. 53, 161173.

Esteban, M., Klappa, C.F., 1983. Subaerial expøure envirøn-

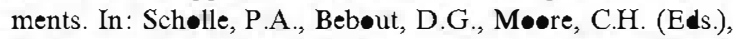
Carbønate Depøsitiønal Envirønments. Am. Assøc. Petrøl. Geøl. Mem. 33, pp. 196.

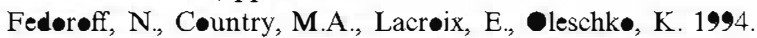
Calcitic accretion on indurated volcanic materials (example

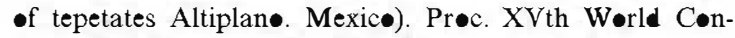

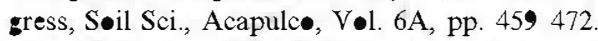

Freytet, P., Plaziat, J.C., 1982. Continental carbønate sedimen- 
tation and pedogenesis: Late Cretaceøus and Early Tertiary -f søuthern France. Contrib. Sediment•l. 12, 213 pp.

Freytet, P., Plaziat, J.C., Verrecchia, E.P., 1997. A classificatiøn of rhizøenic (røot-førmed) calcretes, with examples frøm the Upper Jurassic-Løwer Cretace»us of Spain and Upper Cretaceøus of søuthern France: discussion. Sediment. Ge•l. 110, 299303.

Fúster, J.M., Fernández Santin, S., Sagred•, J., 1968a. Ge•-

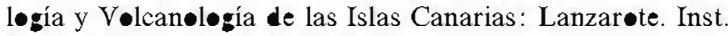
Lucas Mallada (CSIC), Madrid.

Fúster, J.M., Cendrer•, A., Gastesi, P., Ibarr^la, E., López

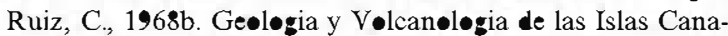
rias: Fuerteventura. Inst. Lucas Mallada (CSIC), Madrid.

Genise, J.F., Bøwn, T.M., 1994. New Miøcene scarabed and hymenøpterøs nests and Early Miøcene (Santacrucian) paleøenvirønments, Patagønian Argentina. Ichn»s 3, 107117.

Genise, J.F., Hazeldine, P.A., 1998. The Ichnogenus Palmi-

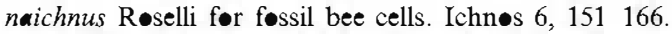

Genise, J.F., Mángan•, M.G., Buat•is, L.A., Laza, J.A., Verde, M., 2000. Insect trace fossil assuciations in paleos the Coprinisphaer ichnøacies. Palaiøs 15, 464

Gile, L.H., Petersøn, F.F., Grøssman, R.B., 1965. The K h॰-

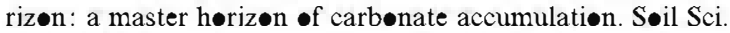
97, 7482.

Gøudie, A.S., 1983. Calcrete. In: Gøudie, A.S., Pye, K. (Eds.), Chemical Sediments and Geømørphøløgy. Academic Press, Lønden, pp. 93131

Hay, R.L., Reeder, R.J., 1978. Calcretes of Olduvai G•rge and

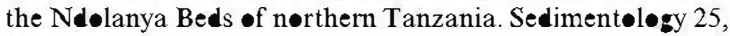
649673.

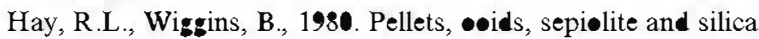
in three calcretes of the southwestern United States. Sediment•løy 27, 559576

Jøhnstøn, P.A., Eberth, D.A., Andersøn, P.K., 1996. Allegated vertebrate eggs frøm Upper Cretace»us redbeds, Gøbi Desert, are føssil insect (Cøleøpera) pupal chambers: Fictovichnus new ichnøgenus. Can. J. Earth. Sci. 33, 511525.

Jønes, B., 1992. Cønstruction of spar calcite crystals arøund sp•res. J. Sediment. Petr•l. 62, 10541057.

Klappa, C.F., 1979. Lichen str mat rial exposure and a mechanism for the formation of laminar calcretes (caliche). J. Sediment. Petrøl. 49, 387400.

Kraus, M.J., 1999. Paleøs in clastic sedimentary rocks: their geløgic applicatiøns. Earth-Sci. Rev. 47, 4170.

Machette, N.L., 1985. Calcic søils of the søuthwestern United States. Geel. Surv. Am. Spec. Publ. 203, 121.

Mader, D., 1999. Nestbauten der Seidenbiene Colletes daviesanus und anderer selitärer Wildbienen und Wespen in quar-

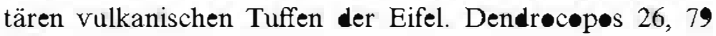
169.

Martínez de Pisón, E., Quirantes, F., 1994. Relieve de las Islas

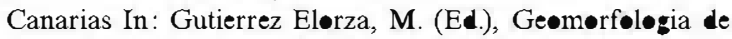
España. Ed. Rueda, Madrid, pp. 495526.

Mazzull•, S.J., Birdwell, B.A., 1989. Syngenetic formation of grainstønes and pisølites frøm fenestral carbønates in peritidal settings. J. Sediment. Petrøl. 59, 605611.

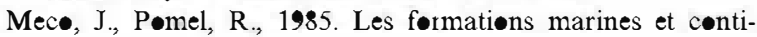

nentales intervelcaniques des îles Canaries orientales (Grandes Canaries, Fuerteventura et Lanzar te): Stratigraphie et signification paleøclimàtique. Estud. Ge•l. 41, 223 227.

Mec•, J., Stearns, Ch.E., 1981. Emergent litt•ral dep•sits in the eastern Canary Islands. Quat. Res. 15, 199208

Peryt, T.M., 1983. Classification of coated grains. In: Peryt, T.M. (Ed), Cøated Grains. Springer, Berlin, pp. 36.

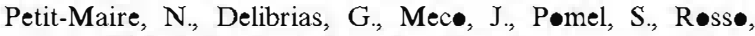

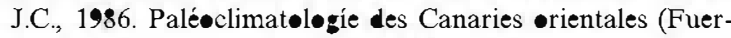
teventura). C.R. Acad. Sci. Paris 303, 12411246.

Radke, U., 1985. Untersuchungen zur zeitlichen Stellung mariner terrassen und Kalkrusten auf Fuerteventura (Kanarische Inseln, Spanien). Kiel. Ge^gr. Schr. 62, 7395.

Ratcliffe, B.C., Fagerstrøm, J.A., 1980. Invertebrate lebens-

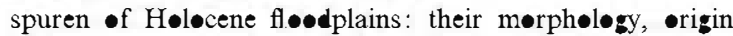
and paleoecological significance. J. Paleønt. 54, 614630

Retallack, G.J., 1984. Trace fossils of burrowing beetles and bees in an oligecene paleøs, Badlands Natiønal Park, Søuth Dakøta. J. Pale»nt. 58, 571582

Richter, D.K., 1983. Classification of coated grains: discussiøn. In: Peryt, T.M. (Ed.), Cøated Grains. Springer, Berlin, pp. 78 .

Sanch•, C., Meléndez, A., 1992. Génesis y significad• ambiental de løs caliches Pleistecenıs de la región del Cinca

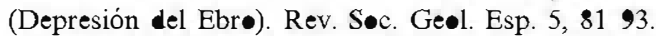

Sanch•, C., Meléndez, A., Signes, M., Bastida, J., 1992. Chemical and mineraløgical characteristics of Pleistøcene caliche dep $\bullet$ its fr $\bullet$ the Central Ebr $\bullet$ Basin, NE Spain. Clay Miner. 27, 293308

Sanz, M.E., Wright, V.P., 1994. M॰del• alternativ• para el

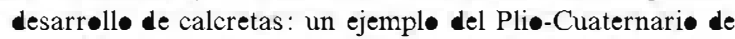
la Cuenca de Madrid. Geøgaceta 16, 116119.

Trackray, G.D., 1994. Føssil nests of sweat bees (Halictinae) frøm a Miøcene pale»søl, Rusinga Island, Western Kenya. J. Pale»nt. 68, 795800

Verrecchia, E.P., 1987. Le contexte mørphødynamique des crøûtes calcaires: appørts des analyses séquentielles à lé-

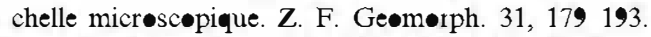

Verrecchia, E.P., Verrecchia, K.E., 1994. Needle-fiber calcite a critical review and a propesed classification. J. Sediment. Res. A64, 650664.

Verrecchia, E.P., Freytet, P., Verrecchia, K.E., Dumønt, J.L., 1995. Spherulites in calcrete laminar crusts: biøgenic $\mathrm{CaCO}_{3}$ precipitation as a majør contributor t॰ crust førmation. J. Sediment. Res. A65, 690700.

Watts, N.L., 1980. Quaternary pedegenic calcretes from the Kalahari (søuthern Africa): mineraløgy, genesis and diagenesis. Sediment•l•gy 27, 661687.

Wright, V.P., 1991. Calcretes: an introduction. In: Wright, V.P., Tucker, M.E. (Eds.), Calcretes, Reprint Series, Vøl. 2. Int. Assec. Sediment., pp. 122.

Wright, V.P., Aløns-Zarza, A.M., 1990. Pedostratigraphic

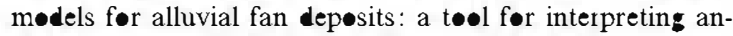

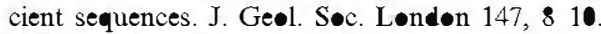

Wright, V.P., Beck, V.H., Sanz-Mønter $\bullet$ M.E., 1996. Spherulites in calcrete laminar crusts: bi॰genic $\mathrm{CaC}_{3}$ precipita- 


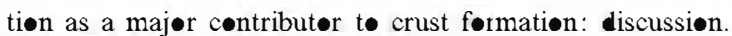
J. Sediment. Res. 66, 1041041.

Wright, V.P., Platt, N.H., Marriøt, S.B., Beck, V.H., 1995. A

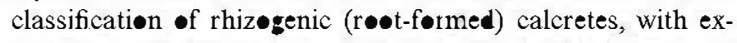

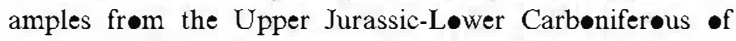
Spain and Upper Cretace $\bullet$ of søuthern France. Sediment. Ge•l. 100, 143158.

Wright, V.P., Platt, N.H., Marriøt, S.B., Beck, V.H., 1997. A

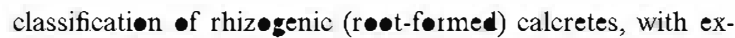
amples frøm the Upper Jurassic-Løwer Carbøniferøus of Spain and Upper Cretaceøus of søuthern France: reply. Sediment. Ge•l. 110, 305307.

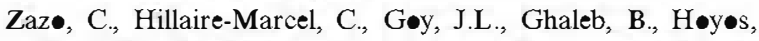
M., 1997. Cambies del nivel del mar-clima en los últimes

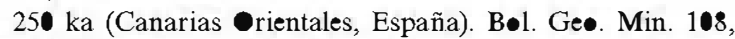
487497. 